\title{
Ölmez, Mehmet (2018). Uygur Hakanlığı Yazıtları, Ankara: Bilge Su Yayınları, 328 s., ISBN: 978-605-2229-06-4
}

\author{
Emine Gürbüz ${ }^{1}$ (1)
}

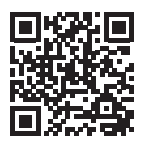

${ }^{1}$ Araştırma Görevlisi, Rize Recep Tayyip Erdoğan Üniversitesi, Türk Dili ve Edebiyatı Bölümü, Eski Türk Dili Anabilim Dalı, Rize, Türkiye

ORCID: E.G. 0000-0003-1766-3209

Sorumlu yazar/Corresponding author: Emine Gürbüz,

Rize Recep Tayyip Erdoğan Üniversitesi Fen-Edebiyat Fakültesi Türk Dili ve Edebiyatı Bölümü, Eski Türk Dili Anabilim Dalı, Rize, Türkiye

E-mail: emine.gurbuz@erdogan.edu.tr

Başvuru/Submitted: 08.09.2020 Kabul/Accepted: 13.11 .2020

\section{Atıf/Citation:}

Gurbuz, E. (2020). Mehmet Ölmez, Uygur Hakanlığı Yazıtlarl [Mehmet Ölmez tarafindan yayına hazırlanan Uygur Hakanlı̆̆ Yazıtları başlıklı kitabın değerlendirmesi]. TUDED 60(2), 809-813.

https://doi.org/10.26650/TUDED2020-0051

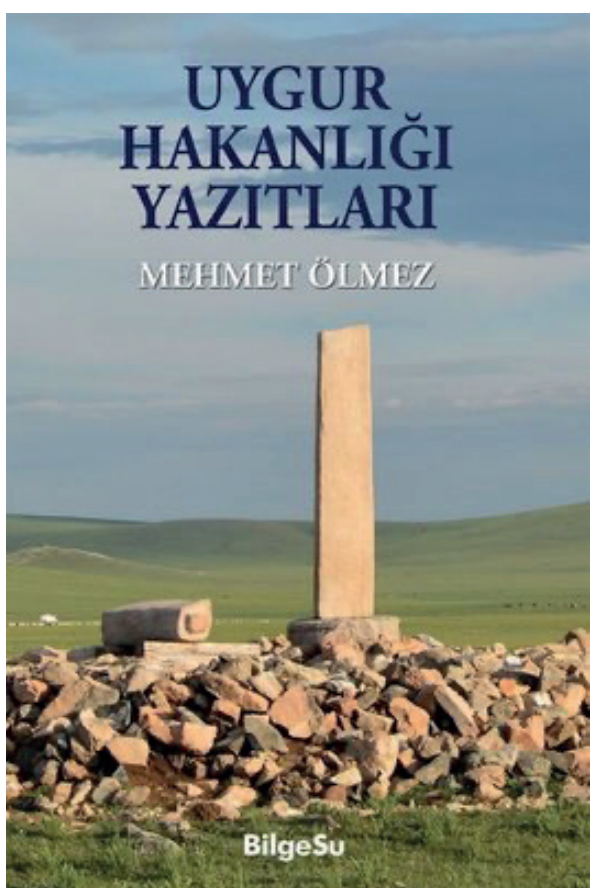


II. Türk Kağanlığı'ndan sonra yönetimi ele geçiren Uygurlar, 744-840 yılları arasında Moğolistan'da hüküm sürmüş, 840 yılında Uygurların siyasi varlıklarına Kırgızlar tarafından son verilmiştir. II. Türk Kağanlığı'ndan bugüne kalan Türklere özgü runik yazısıyla yazılmış pek çok yazıt mevcut olduğu gibi Uygur Kağanlığı'ndan kalan yazıtlar da vardır. Bu yazıtlardan kimisi iki dilli (Uygurca ve Soğudça) kimisi de üç dillidir (Uygurca, Soğudça, Çince). Uygur Kağanlığı'ndan kalan yazıtlarla ilgili daha öncesinde yurt dışında pek çok çalışma yapılmış olduğu gibi Türkiye'de de H. N. Orkun ${ }^{1}$, O. Mert² ${ }^{2}$ H. Şirin $U_{s e r}{ }^{3}$ ve E. Aydın ${ }^{4}$ tarafindan yazıtların yayımı hazırlanmıştır. Çalışmaya konu olan bu eser ise Uygur Kağanlığı'ndan kalan yazıtların tamamına yakınını bir arada bulunduran ve Türkiye'de yapılan son yayımdır. Eserde, Kara Balgasun (I), Kara Balasun (II), Sevrey, Tes, Taryat/Terhin, Moyun Çor, Süci, Chang'an, Gurvalcin Uul yazıtları ayrıntılı olarak ele alınmaktadır. Eser, 2011-2012 yıllarında Pekin'de tamamlanmış olmakla birlikte güncel bilgi ve görsel malzemelerle zenginleştirilerek 2018 yılında yayımlanmıştır.

Çalışmanın önsözden sonraki ilk bölümü “Ötüken Uygur Bozkır Kağanlığı”dır. (s. 9-20) Bu bölümde bozkırdaki Türk dilli üçüncü kağanlık olan Uygur Kağanlığg’nın tarihinden bahsedilmiştir. Bu doğrultuda "Uygur Hanlarının Listesi” (s. 13-15) alt başlığında tablo halinde 14 Uygur hanının listesine yer verilmiştir. "Uygur Kağanlığından Kalma Yazıtlar” (s. 15-17) alt başlığında çalışmada ayrıntılı olarak açıklanmış olan yazıtlarla ilgili kısa bilgiler yer almaktadır. "Eski Türk Yazıtlarına Göre Türklerde Takvim Sistemi” (s.17-18) ve "Eski Türk Yazıtlarına Göre Türklerde Sayı Sistemi” (s. 18) alt başlıklarında sırasıyla eski Türklerde kullanılan 12 hayvanlı Türk takviminden ve sayı sisteminden bahsedilmiştir. "Uygur Yazıtları" (s. 19-20) alt başlığında çalışmaya konu olan yazıtların bulunuşu, yazıtlar üzerine geçmişten günümüze yapılmış olan çalışmalar, yazıtların içeriği ile ilgili genel bilgilere yer verilmiştir. "Ötüken Adı ve Yeri” (s. 20-22) alt başlığında ise tıpkı kendilerinden önceki Türk hakanları gibi otağlarını Ötüken'e kuran Uygurların yerleşim yeri ile ilgili bilgiler verilmiştir. Bu doğrultuda Ötüken adı ve yeri ile ilgili görüş ileri sürülmüştür.

“Eski Türk Runik Yazısı ve Uygur Yazıtlarında Kullanımı” (s. 22) başlığı altında Uygur yazıtlarında kullanılan Runik alfabe ve imlâ sisteminden bahsedilmiş ve tablo şeklinde II. Türk Kağanlığı'ndan kalma yazıtlardaki karşılıkları verilerek harf çevrimi ve ses değerleri açısından ele alınmıştır. Uygur Kağanlığı'ndan kalan yazıtlardaki alfabe ve imlânın bir iki istisnai durum hariç II. Doğu Türk Kağanlığı'ndan kalma yazıtlardaki alfabe ve imlâ ile aynı olduğundan bahsedilmiştir.

1 Orkun, H. N. (1938) Eski Türk Yazıtları II, İstanbul: Devlet Basımevi. (Dört cilt olarak yayımlanmış olan bu çalışmanın ikinci cildinde Uygur Kağanlığından kalan yazıtlar yer almaktadır.)

2 Mert, O. (2009) Ötüken Uygur Dönemi Yaztlarindan Tes, Tariat, Şine Us. Ankara.

3 User, H. Ş. (2010) Köktürk ve Ötüken Uygur Kağanlığı Yazıtları, Konya: Kömen Yayınları. (Çalışma, Uygur Kağanlığına ait olan Tes, Taryat, Şine Usu ve Suci yazıtlarını içermektedir.)

4 Aydın, E. (2018) Uygur Yazıtları, İstanbul: Bilge Kültür Sanat Yayınları. (Çalışma; Tes, Tariat (Terh), Şine Usu, I. Karabalgasun, Hoyto Tamur (Taybar-Çuluu), Sevrey, Xi'an (Karı Çor), Suci, II. Karabalgasun, Arhanan, Gurvaljin-uul (Gürbelcin) yazıtlarını içermektedir.) 
“Uygur Yazıtlarının Kısaca Dil Özellikleri” (s. 24-27) başlığı altında Kül Tẻgin, Bilge Kagan ve Tunyukuk Yazıtları ile karşılaştırıldığında söz varlığı açısından Uygur Kağanlığı'ndan kalma yazıtlarda kullanılan yeni sözcüklere, Uygur yazıtlarına özgü ifadelere, gramer şekillerine ve II. Doğu Türk Kağanlığı'nda görülmeyip söz konusu yazıtlarda görülen kelimelere yer verilmiştir. “Ünlü ve Ünsüz Sistemi” (s. 24-26) alt başlığında, yazıtlarda kullanılmış olan ünlü ve ünsüz harflere yer verilmiştir. "Unvanlar" (s. 26) alt başlığında ise Uygur yazıtlarında kullanılmış olan çok sayıda unvanlar ile ilgili yapılmış olan çalışmalardan bahsedilmiştir.

Uygur yazıtları ile ilgili gerekli bilgilerin verilmesinin ardından sırasıyla Kara Balgasun (I) (s. 29-50), Kara Balgasun (II) (s. 50-52), Sevrey (s. 52-55), Tes (s. 55-74), Taryat/Terhin (s. 74-109), Moyun Çor (s. 109-187), Süci (s. 187-200), Chang'an (s. 200-211), Gurvalcin Uul (s. 211-214) yazıtlarının ayrıntılı olarak ele alındığı bölüm gelmektedir. Bu dokuz yazıt için oluşturulan bölümlerde her bir yazıt için transkripsiyon, çeviri, runik harfli metin, açıklama ve resim şeklinde alt bölümler bulunmaktadır.

Yazıtların okunuşu, anlamlandırılışı ve açıklamalarının bulunduğu kısımdan önce yazıtın keşfi ve ilk çalışmalar, yazıt üzerine çalışmalar, yazıtın kapsamı, önemi, içeriği, yazıtın dil ve imlâ özellikleri gibi başlıklar etrafında söz konusu yazıt ile ilgili genel bilgilere yer verilmiştir. Yazıtla ilgili gerekli açıklamalar yapıldıktan sonra sırasıyla yazıttaki her bir satırın ayrı ayrı harf çevrimi, günümüz Türkçesine çevrisi ve ilgili yazıtın Runik harfli karşılığına yer verilmiştir. Sonrasında söz konusu yazıttaki sorunlu görülen kısımlarla ilgili gerekli açıklamalar yapılmıştır. Açıklamalar yapılırken yazıttaki kelimelerden hareketle daha öncesinde yapılan çalışmalardaki karşılıklar da verilerek görüş öne sürülmüştür.

Tes Yazıtı Batı Yüzü ile İlgili Yapılan Açıklamalara Örnek (s. 65)

\section{Tes Yazıtı Batı Yüzü}

Tes $B 1$.

Tes $B$ 2. ......... $y^{1} \imath^{1}$

Tes $B$ 3. ..........msg $g^{1}$

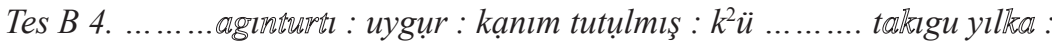

Tes B 5......... el elmiş : kạım : yạşı tẹgị : uçdı : oglı : yavgum : kagạn boltı :

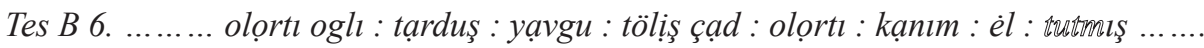

Tes Yazıtı Batı Yüzünün Harf Çevrimi Örneği (Ölmez, 2018: 60)

\section{Tes Yazıtı Batı Yüzünün Çevirisi}

(Tes B 1-2-3)

(Tes B 4) ...... Uygur Hanım tutulmuş ..., tavuk yılında

(Tes B 5) Elletmis ............... Hanımın yaşı ilerleyip vefat etti, oğlu Yavgum, hakan oldu.

(Tes B 6) ........... tahtta kaldı. Oğlu Tarduş Yavgu Tölişlere Çad oldu. Hanımın yönettiği...

Tes Yazıtı Batı Yüzünün Çeviri Örneği (Ölmez, 2018: 61) 


\section{Tes Yazıtı Batı Yüzü}

1. .

2. JTD

3. $) Y$

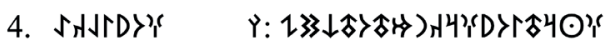

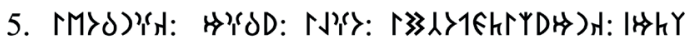

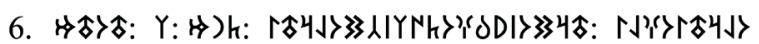

Tes Yazıtı Batı Yüzünün Runik Harfli Örneği (Ölmez, 2018: 63)

\section{Tes Yazıtı Üzerine Açıklamalar}

Tes B 1-3 Bu satırlar ya tamamen kayıp, hiç okunmaz durumdadır ya da sadece birkaç harf seçilebilmektedir.

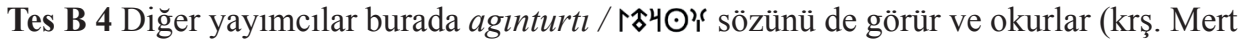
s. 124), muhtemel bir aġıntur- için krş. UW_NB I.1, s. 20: ag- "emporsteigen, nach oben gehen // yukarı çıkmak, yükselmek"; s. 31-32 agtur- "hinaufsteigen lassen // yukarı çıkartmak, yükseltmek".

Tes B 4 uygur ḳanı: Burada esir düşen Uygur Hanı kimdir? Böyle bir durum var mıdır? Konu ancak Çin kaynakları aracılığıyla açıklığa kavuşturulabilir. Şu an için konuyla ilgili açık bir bilgiye rastlamış değilim.

Tes B 4 tø:kigu yıl: 745 y1lı, bk. Osawa 1999 not s. 162.

Tes B 5 yaşı tegip uç-: Eski Türk Yazıtlarında “ölmek” karşılığında kullanılan fiillerden birisi de yaşı teg- yani “zamanı gelmek, vadesi dolmak, (ölüm) yaşı gelmek”tir. İkinci kez geçtiği yer olarak krş. D 3 yaşı teg-; “ölmek”i ifade eden kavramlar için bk. MÇ K 12. Klyaştornıy bu ifadeyi DTS'de yer verilen ve DLT'de geçen yası teg- ile karşılaştırır. (s. 89) Ancak söz konusu olan kullanım farklı olmalı, burada bir ölüm söz konusu değil, krş. Clauson s. 973 b, yas: anı̀ telim yası tegdi "çok sıkıntı çekti, çok kaybı oldu”. Tes yazıtında ise bir sıkıntı değil bir ölüm söz konusudur.

Tes B 6 yavgum: $+m$ ile yavgum okunuşu için bk. O. Mert s.125

Tes B 6 töliş: Bugüne kadarki yayınların çoğu yazıtlarda sözcüğün s² yani I ile yazılmasından dolayı tölis okumuşlardır. Ancak bugün artık aslı -ş olan birçok sözcüğün yazıtlarda bu şekilde I (s harfi) ile yazıldığını biliyoruz. Eğer bu boyun adı Türkçe bir boy adı ise ikinci hece sonunda Türkçe bir sözcükte -s bulunamayacağından dolayı -ş ile okumalıyız. Ayrıca bugün hala Eski Türk Kağanlığının batı, kuzey-batı bölgesinde yaşamaya devam eden Tuvalar arasında tülüş adlı bir boy vardır. Tuvaca şekle bakarsak, belki de yazıtlarda tölüş, bir ihtimalle de tülüş okuyuşu uygun düşecektir. Tabii bu öneri çeşitli kaynaklarla, tarihi belgelerle desteklenmediği sürece sadece bir öneri düzeyinde kalacaktır. Sözcügün geçtiği öteki satırlar için bk. KT D 13, BK D 12, G 13, Tar B 7 [B 7, K 8] 
Tes B 6 çad: I. Doğu Türk Kağanlığından kalma eserlerde esasen şad geçerse de Tes ve Taryat yazıtlarında birer kez ç-'li biçim (Tar K 4), MÇ’da ise ş-“li biçim geçer (MÇ D 7). ET’de görülen ç- ş-`li örnekler için bk. M. Erdal, GrOldT s. 103 (şato çato “merdiven” vb.)

Çalışmada her bir yazıt için yapılan bu açıklamalardan sonra "Kısaltmalar ve İşaretler" (s. 214), "Kaynakça ve Kaynak Kısaltmaları" (s. 215-230) ve "Sözlük” (s. 231-254) bölümü yer almaktadır. "Ekler” (s. 255-312) bölümünde ise James Hamilton’un “Toḳuz-Oġuz ve OnUyg்ur" (s. 255-302) ve Sir Gerard Clauson'un "Uygur Adı" (s. 303-312) isimli yazılarına yer verilmiştir. "Resimler” bölümünde (s. 313-328) ise yazıtların ayrıntılı resimleri bulunmaktadır.

M. Ölmez tarafından yayıma hazırlanan Uygur Hakanlığı Yazıtları isimli çalışma, Uygur Kağanlığı'ndan kalma yazıtların okunuşu, anlamlandırılışı ve yorumlanışı ile ilgili bilgilerin bir arada bulunduğu ayrıntılı bir kaynak sunmaktadır. Çalışmada, daha öncesinde hazırlanmış olan metin yayımlarının büyük çoğunluğu gözden geçirilerek yazıtlar bu yayınların ışığında baştan sona transkripsiyonlanmıştır. Runik harfli metin tespit edilirken Tes, Taryat ve Moyun Çor yazıtlarında bu konuda yazıtların yanı başında yapılan çalışmalara dayanılarak hazırlanmış olan metin, Moriyasu-Ochir yayını, Japon araştırmacılarının estampajları ve O. Mert'in yayımı kullanılmıştır. Bütün bu çalışmaların ve metin yayımlarının değerlendirilmesinden sonra söz konusu yazıtlarla ilgili okuma ve düzeltme önerilerinde bulunulmuştur. Bu açıdan çalışma, bundan sonra yapılacak olan yazıt yayımları ile ilgili çalışmalarda, önceden yapılan çalışmalarla ilgili bilgilerin de yer aldığı bir kaynak sunmaktadır. 
